https://helda.helsinki.fi

\title{
Fiscal Devaluation in a Monetary Union
}

\section{Engler, Philipp}

\section{3}

Engler , P , Ganelli , G , Tervala , J \& Voigts , S 2013 , ' Fiscal Devaluation in a Monetary

Union ', Diskussionsbeiträge des Fachbereichs Wirtschaftswissenschaft der Freien

Universität Berlin , no. 2013/18 , pp. 1-28 . <

http://edocs.fu-berlin.de/docs/receive/FUDOCS_document_000000019315 >

http://hdl.handle.net/10138/42733

publishedVersion

Downloaded from Helda, University of Helsinki institutional repository.

This is an electronic reprint of the original article.

This reprint may differ from the original in pagination and typographic detail.

Please cite the original version. 


\section{Fiscal Devaluation in a Monetary Union}

Philipp Engler

Giovanni Ganelli

Juha Tervala

Simon Voigts

School of Business \& Economics

Discussion Paper

Economics

$2013 / 18$ 


\title{
Fiscal Devaluation in a Monetary Union
}

\author{
Philipp Engler, Giovanni Ganelli, \\ Juha Tervala and Simon Voigts*
}

\begin{abstract}
Between 1999 and the onset of the economic crisis in 2008 real exchange rates in Greece, Ireland, Italy, Portugal and Spain appreciated relative to the rest of the euro area. This divergence in competitiveness was reflected in the emergence of current account imbalances. Given that exchange rate devaluations are no longer available in a monetary union, one potential way to address such imbalances is through a fiscal devaluation. We use a DSGE model calibrated to the euro area to investigate the impact of a fiscal devaluation, modeled as a revenue-neutral shift from employers' social contributions to the Value Added Tax. We find that a fiscal devaluation carried out in 'Southern European countries' has a strong positive effect on output, but a mild effect on the trade balance of these countries. In addition, the negative effect on 'Central-Northern countries' output is weak.
\end{abstract}

Keywords: Fiscal devaluation, fiscal policy, euro area, currency union, current account JEL classification: E32, E62, F32, F41

* Philipp Engler: Freie Universität Berlin, School of Business and Economics, Boltzmannstr. 20, 14195 Berlin, Germany, email: philipp.engler@fu-berlin.de; Giovanni Ganelli: IMF Regional Office for Asia and the Pacific, Chiyoda-ku, Tokyo 100-0011, Japan, email: gganelli@imf.org; Juha Tervala (corresponding author): University of Helsinki, Department of Political and Economic Studies, P.O. Box 17, FI-00014 University of Helsinki, Finland, phone: +358505862968, fax: +358919128736, email: juha.tervala@helsinki.fi; Simon Voigts: Humboldt-Universität zu Berlin, School of Business and Economics, Spandauer Straße 1, 10178 Berlin, Germany, email: s.voigts@huberlin.de. 


\section{Introduction}

According to the theory of optimal currency areas (Mundell 1961), entering a currency union implies various costs and benefits for member countries. Gains include smaller transaction costs and elimination of exchange-rate uncertainty for cross-border transactions, which can lead to increased intra-union trade and Foreign Direct Investments. For some countries, delegating monetary policy to a super-national central bank might also entail increased credibility, resulting in lower and more stable inflation and government bond yields.

On the other hand, from the point of view of individual countries, one of the most important costs of joining a currency union is the loss of an independent monetary policy, which prevents countries from calibrating monetary policy to domestic objectives and from carrying out exchange rate devaluations aimed at improving competitiveness of their exports. This can bring about situations in which, within a currency union, some countries accumulate external surpluses and others accumulate external deficits. This dynamic can ultimately lead to balance of payment crises, with potentially dire consequences for growth and economic and social stability.

Figure 1: Real Effective Exchange Rate (deflator: consumer price indices - 17 trading partners) in selected euro area countries 1/. Source: Eurostat (2013)

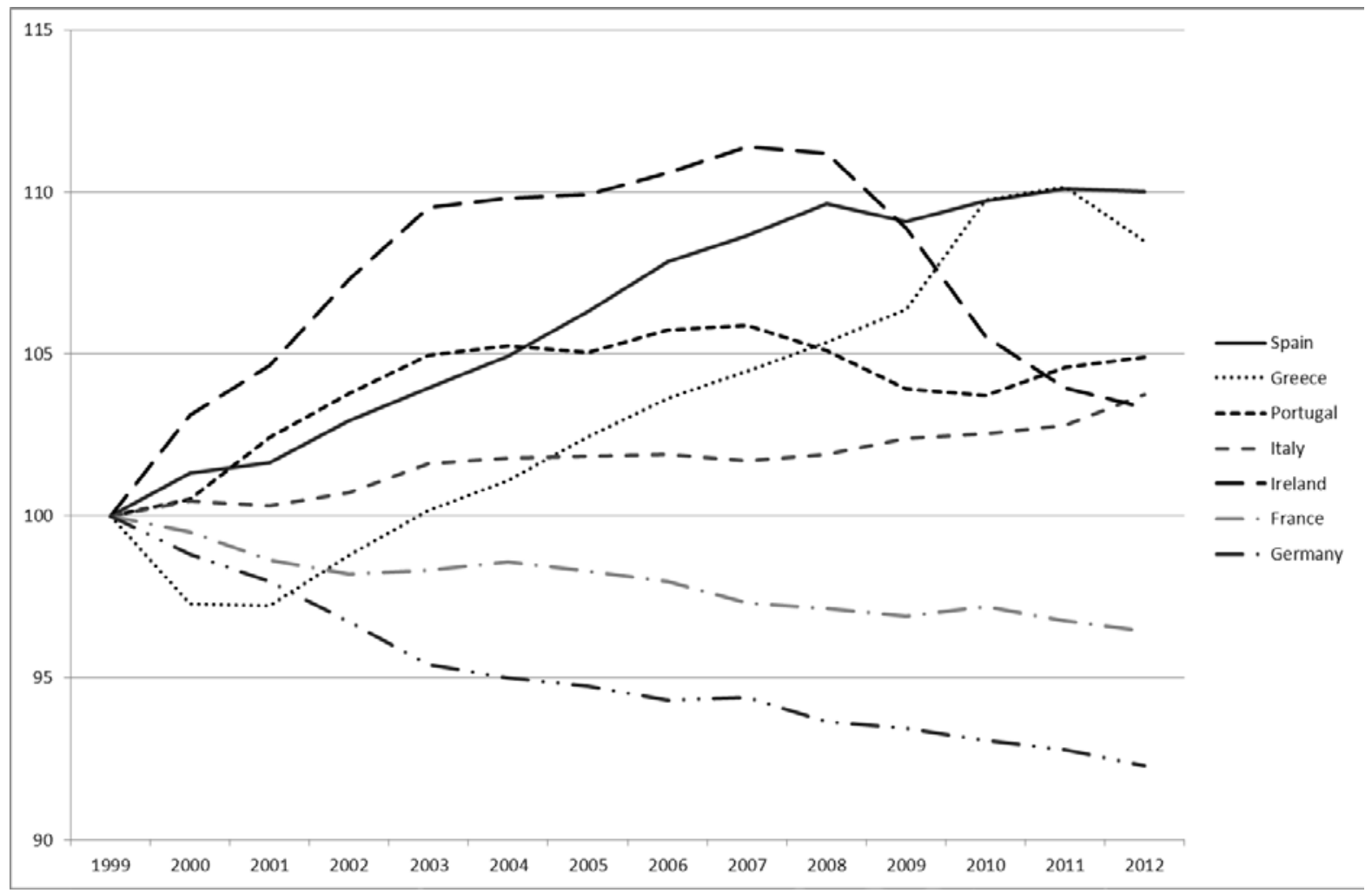

1/ An increase denotes an appreciation of the real exchange rate.

Developments in the euro area since the creation of the single currency in 1999 and the onset of the global economic crisis in 2008 provide an example in this regard. During this period real exchange rates in various countries, such as Greece, Ireland, Italy, Portugal and Spain, have appreciated relative to the rest of the euro area (see Figure 1). 
This divergence in competitiveness was reflected in the emergence of external imbalances within the euro area, with some countries - such as Austria, Belgium, Finland, Germany, Luxemburg and The Netherlands-accumulating current account surpluses, and others-such as Greece, Ireland, Italy, Portugal and Spain-accumulating deficits. Figure 2 below shows the dynamics of the aggregate current account balances of the 'Central-Northern European countries' (Austria, Belgium, Finland, France, Germany, Luxemburg and The Netherlands) and those of the 'Southern European countries' (Greece, Ireland, Italy, Portugal and Spain). ${ }^{1}$

\section{Figure 2: Current account surplus (\% of GDP) of Central-Northern European countries ('Central-Northern European countries') and Southern European countries ('Southern European countries'). Source: World Bank (2013)}

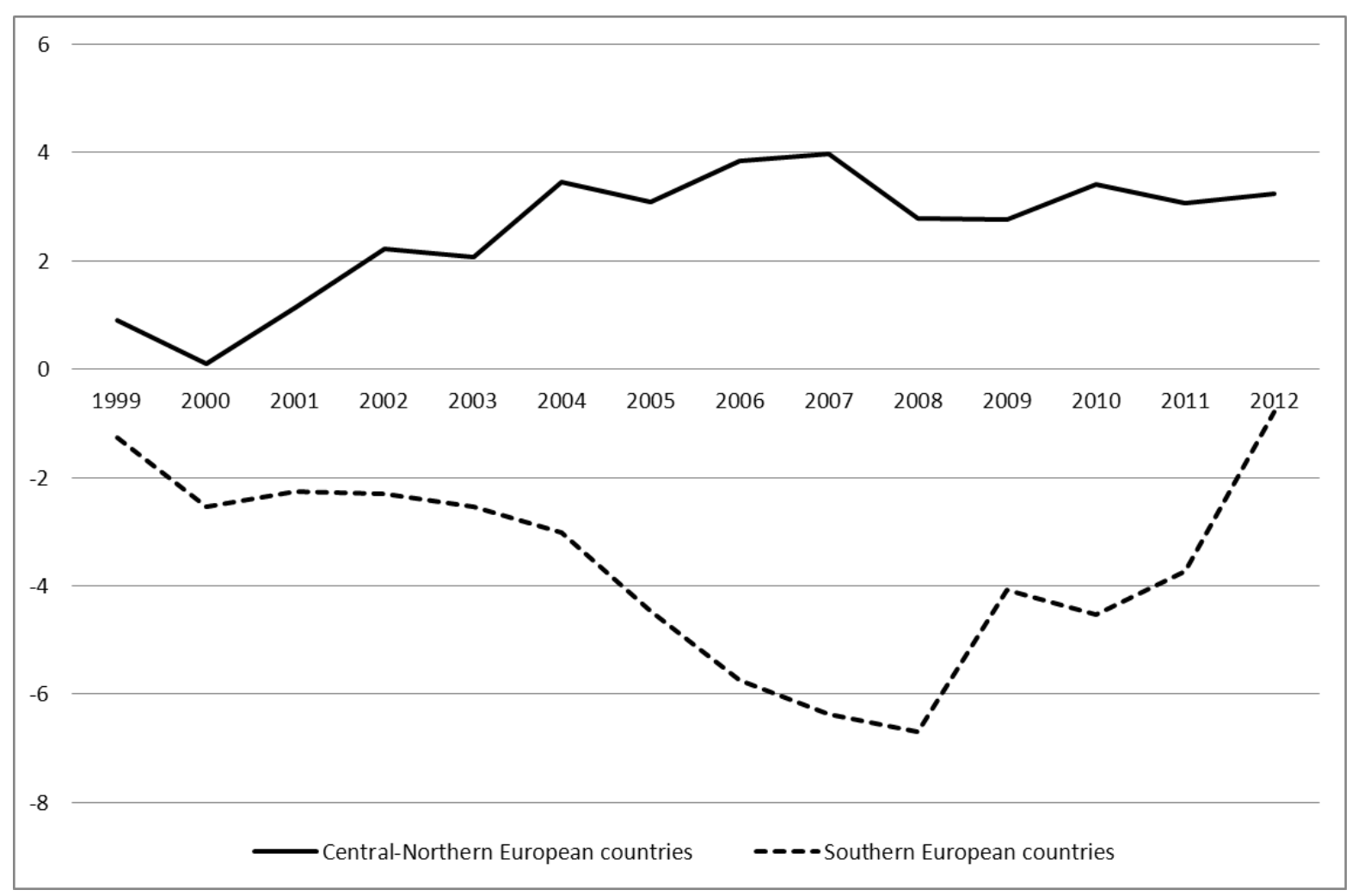

The loss of competitiveness in 'Southern European countries' and the attendant emergence of withinunion external imbalances are widely regarded as important factors contributing to the euro area crisis. Gourinchas and Obstfeld (2012) and Reinhart and Rogoff (2009), for example, stress that real exchange rate appreciations and current account deficits are amongst the most robust and significant predictors of financial crises.

Against this background, correcting within-union imbalances is a prerequisite for overcoming the euro area crisis and putting the euro area economy back on a sustainable path. Given that exchange rate devaluations are no longer available to individual countries in the euro area, one potential way to address such imbalances is by using fiscal policy, which can, under certain circumstances, replicate the impact of exchange rate devaluations.

\footnotetext{
1 Since we have included Ireland in this group, a more precise denomination would be 'Ireland and Southern European countries' but in what follows we will use the 'Southern European countries' denomination for simplicity.
} 
The idea of 'fiscal devaluations' is not a new one, and goes back to Keynes (1931), who stated:

Precisely the same effects as those produced by a devaluation of sterling by a given percentage could be brought about by a tariff of the same percentage on all imports together with an equal subsidy on all exports, except that this measure would leave sterling international obligations unchanged in terms of gold.

In its modern incarnation, Keynes' idea can be implemented not by using tariffs and subsidies—-which would be inconsistent with free trade agreements in economic and monetary unions-but rather by a policy mix entailing a reduction in employers' social contributions (SCR) and an increase in the Value Added Tax (VAT). ${ }^{2}$ Since the latter is reimbursed to exporters and levied on importers, the overall effect of such fiscal reform is to make domestic producers more competitive.

In this paper we develop a two-country New Keynesian model, where the two countries are calibrated to represent the 'Central-Northern countries' (Austria, Belgium, Finland, France, Germany, Luxemburg and The Netherlands) and the 'Southern countries' (Greece, Ireland, Italy, Portugal and Spain) of the euro area. We use our model to analyze the international transmission of a revenueneutral fiscal devaluation implemented in 'Southern European countries', which we model as a shift from SCR toward VAT. The motivation for our chosen approach is that the size of 'Southern European countries' in the euro area is large enough to affect 'Central-Northern European countries'. More importantly, the goal of a fiscal devaluation in 'Southern European countries' is not only to correct their loss of competitiveness and current account deficits, but also to reduce the current account surpluses of the 'Central-Northern European countries'. Our approach highlights international transmission channels and allows us to analyze not only the effects of the fiscal devaluations in 'Southern European countries' on their own economies, but also the impact on economic variables in 'Central-Northern European countries'.

Although several existing papers have looked at fiscal devaluations, most of them use small open economy frameworks, and as such, they cannot analyze the international spillover effects of fiscal devaluations. Unlike these papers, our two-country framework is well equipped to address such issues. As we explain below, our paper also differentiates itself from the only three contributions to this literature that we know of, which use a two-country framework (Farhi et al. 2013; Franco 2010; Lipinska and von Thadden 2012). In particular, our paper is, to the best of our knowledge, the first one to address the international transmission of a "pure" fiscal devaluation, i.e. a fiscal reform in which the increase in the VAT is compensated by a reduction in SCR. ${ }^{3}$

We use a model of a monetary union with imperfect competition in the labor market and deviations from Ricardian equivalence, modeled by the presence of credit-constrained agents. As mentioned, we calibrate the two countries in the model to represent 'Southern countries' and 'Central-Northern countries' of the euro area. In particular, the relative sizes of the two countries in the model are set to match the relative GDPs of the 'Southern European countries' and 'Central-Northern European countries' regions. We model the fiscal devaluation as an ex post revenue-neutral shift from SCR to VAT. The sizes of tax shocks in 'Southern European countries' are set in such a way that VAT revenues are increased by 1 percent of GDP, while SCR revenues are reduced by 1 percent of GDP.

\footnotetext{
2 CPB (2013, Section 2) surveys the literature on fiscal devaluations.

3 Lipinksa and von Thadden (2012) model fiscal devaluation as a reduction in labor income taxes, rather than in SCR (see more detailed discussion below). Franco (2010) develops a two-country model of a monetary union, but calibrates it to Portugal, virtually ignoring the international transmission of fiscal devaluations.
} 
Our main finding is that a fiscal devaluation carried out in 'Southern European countries' has a strong positive effect on output and consumption in these countries-while also mildly depreciating their real exchange rate and improving their trade balance-but has a small negative effect on output and consumption in 'Central-Northern European countries'.

A reduction in the SCR in 'Southern European countries' implies lower producer prices, resulting in a reduction of relative prices of 'Southern European countries' goods compared to 'Central-Northern European countries' goods. This causes a shift in demand away from the 'Central-Northern European countries' goods and toward 'Southern European countries' goods, which results in an increase in output in 'Southern European countries'. Due to the Calvo-pricing mechanism, after the initial reaction, a larger fraction of firms in 'Southern European countries' become able to lower their prices. This implies an even stronger expenditure-switching effect after a few quarters. However, the positive effect from lower SCR on 'Southern European countries' output is mitigated by the impact of the VAT increase on 'Southern European countries' prices and the ensuing price-wage dynamics. Immediately after the fiscal devaluation, wages start to adjust upwards in 'Southern European countries'. Given imperfect competition in the labor market in our model, a higher price level, caused by the increase in the consumption tax rate, implies that labor unions require higher nominal wages. Real marginal costs therefore start to adjust toward the original, pre-reform level and the positive effect on output gradually peters out. Even in the long term, however, the positive effect of the reduction in SCR on output still dominates the negative effect of the increase in VAT, and a revenueneutral fiscal devaluation still has a small positive effect on 'Southern European countries' output in the long term.

As a result of the effects described above, 'Southern European countries' output displays a humpshaped response. Under the benchmark parameterization, a fiscal devaluation increases output in 'Southern European countries' by one percent in the third quarter. Our sensitivity analysis confirms the main result, and shows that the peak effect on 'Southern European countries' output is-assuming sticky wages-in the 0.9-1.4 percent range, depending on the parameterization.

We also show that a fiscal devaluation has quite limited impact on the trade balance. In 'Southern European countries', income goes up more in the short term than in the long term. This implies that in the short-term 'Southern European countries' households are temporarily richer, and therefore they save by accumulating net external assets. In the short term, the 'Southern European countries' trade balance improves by 0.2 percent. However, this effect is not permanent. The risk premium in the interest rate parity equation forces bond holdings to return to the initial level in the long term, and the trade balance turns into negative after a few quarters and then reverts to the initial level.

Our results are in line with those of the small open economy models used by the Bank of Portugal (2011) and the European Central Bank (2012), which find that a fiscal devaluation, of 1 percent of GDP, depreciates the real exchange rate (0.3 percent), increases output (0.2-0.6 percent) and improves the current account balance (0.1-0.6 percent of GDP). We find a stronger effect on output in the short term, while the trade balance impact is within range of earlier results.

Lipinska and von Thadden (2012) is the paper most directly related to ours. They use a New Keynesian two-country model of a monetary union with different degrees of financial integration. Our paper differs from theirs in three dimensions. First, they model a fiscal devaluation as a permanent increase in the VAT and a reduction in the labor income tax rate, rather than as a reduction in the SCR, as we do. Second, they do not calibrate their model for a specific country or a group of 
countries, whereas we calibrate the two countries to the relative size of 'Southern countries' and 'Central-Northern countries' within the euro area. Finally, unlike them, we analyze the impact of fiscal devaluations not only on output, but also on the trade balance.

Lipinska and von Thadden (2012) find that, in a region whose size is half of a monetary union, fiscal devaluations tend to be ineffective: they increase domestic output by only 0.05-0.15 percent, compared to 0.9-1.4 percent in our model. In addition, the spillover effect on foreign output is small. The difference between our results and theirs is due to the fact that, as mentioned above, their fiscal devaluation is modeled as a permanent increase in VAT compensated by a reduction in the labor income tax rate. As such, this is not a "pure" fiscal devaluation because, unlike a reduction in SCR, a reduction in the labor income tax does not necessarily imply competitiveness gains for domestic goods. One of our key findings is therefore to find support for the results that a fiscal devaluation, if properly modeled as a reduction in SCRs, can substantially increase output in 'Southern European countries', thus helping to rebalance the euro area economy.

Regarding international transmission effects, we find that a fiscal devaluation in 'Southern European countries' increases output in 'Central-Northern European countries' in the short term, despite the expenditure switching effect favorable to 'Southern European countries'. Since we model monetary policy as following a Taylor rule, a deflation in the monetary union implies that the central bank cuts the interest rate. This expansionary monetary policy increases demand across the whole monetary union, which in the short term more than compensates the negative impact of the expenditure switching effect on 'Central-Northern European countries' output, resulting in a temporary increase in output in these countries. In the medium and long term, as a larger fraction of firms in 'Southern European countries' have become able to lower their price, the expenditure switching effect becomes stronger and dominates the expansionary effect of loosened monetary policy causing output to fall in 'Central-Northern European countries'. The peak effect (the most negative effect) on 'CentralNorthern European countries' output is -0.3 percent.

Very few studies have analyzed the trade effects of fiscal devaluations. Franco (2011) uses a Vector Autoregression (VAR) methodology to analyze the effects of changes of VAT and SCR on real exports and imports in Portugal. He finds that a VAT shock decreases imports, whereas an SCR shock increases exports. De Mooij and Keen (2013) carry out a similar analysis using a panel of OECD countries. Their results suggest that, even within the euro area, a fiscal devaluation might increase the trade balance quite sizably in the short term. De Mooij and Keen's (2013) empirical results imply that raising the VAT rate by 1 percentage points and reducing the SCR rate by 1.7 - the same policy that we calibrate in our model to achieve a 1 percent of GDP redistribution in taxation in 'Southern European countries'-improves net exports by 0.4 percent of GDP. The results of our calibration are broadly consistent with these empirical estimates regarding the effect on the trade balance. In our model, under the benchmark parameterization, the trade balance of 'Southern European countries' improves by 0.2 percent of GDP, a slightly weaker impact than the one found by de Mooij and Keen (2013). Consistent with the empirical evidence, we also find that the effect on the trade balance eventually disappears.

Overall, we find that a fiscal devaluation in 'Southern European countries' depreciates their real exchange rate, increases their output and improves their trade balance. However, the advantageous effects of a fiscal devaluation should not be overplayed. A fiscal devaluation of 1 percent of GDP carried out by 'Southern European countries' depreciates the real exchange rate by 0.3 percent and improves the trade balance by 0.2 percent of GDP, which are quite small effects. Figure 2 shows that 
the current account deficit in 'Southern European countries' was roughly 1 percent of GDP in 2012. We show that a fiscal devaluation of roughly 6 percent of GDP is needed to correct-temporarilythe 1 percent trade balance deficit in 'Southern European countries'. This would imply that the VAT rate needs to be increased by 6 percentage points and it may be difficult to raise VAT rates by such a large amount swiftly. In addition, a fiscal devaluation of 6 percent of GDP depreciates the real exchange rate of 'Southern European countries' only by 1.9 percent. Therefore we would like to stress that, because the benefits from a fiscal devaluation on competitiveness are small relative to the size of the problem, the divergence in competitiveness is best addressed through structural reforms. Our findings suggest that a fiscal devaluation alone would not be sufficient to correct the divergence in competitiveness and the current account imbalance between the 'Southern countries' and 'CentralNorthern countries' in the euro area. Although the fiscal devaluation can be a useful reform to make progress in this direction, in order to be successful, it would need to be part of a wider package of policy reforms aimed at increasing the competitiveness of 'Southern European countries', including for example product and labor market reforms and wage moderation.

The rest of the paper is organized as follows. Section 2 presents the model. Section 3 discusses the parameterization. Section 4 analyzes the international transmission effects of 'Southern European countries' fiscal devaluation. Section 5 concludes the paper.

\section{The Model}

In this section, we develop a New Keynesian open-economy model. The model consists of two regions that have formed a monetary union, two types of infinitely-lived households, imperfect competition and nominal rigidities in goods and labor markets, a central bank and a fiscal authority. The two regions represent the 'Southern European countries' (Greece, Ireland, Italy, Portugal and Spain) and the 'Central-Northern countries' (Austria, Belgium, Finland, France, Germany, Luxemburg and The Netherlands) of the euro area. We assume a continuum of households and normalize the size of the euro area to 1 . Households are indexed by $i \in[0,1]$ and the relative size of 'Southern European countries' ('Central-Northern European countries') is 1- $n(n)$.

\subsection{Households}

\subsubsection{Preferences}

We assume that in each country, following Gali et al. (2007), a fraction $1-\lambda$ of households are Ricardian households and a fraction $\lambda$ are non-Ricardian households. Ricardian households, denoted by superscript RH, optimize their behavior intertemporally and can trade assets. Non-Ricardian households, denoted by superscript NR, do not optimize consumption intertemporally; they consume their current labor income in each period and they do not own assets nor have liabilities. In addition, we assume that Ricardian households own firms. Our decision to include non-Ricardian households is justified by several empirical studies. Mankiw and Campell (1990), for example, find that aggregate consumption can be explained by both permanent and current income. Mian and Sufi (2010) find that credit constraints can explain a large fraction of consumption in a recession. In addition, the euro area suffers from a banking crisis, which harms financial intermediation. In the presentation of the model, we present only the equations for 'Southern European countries', if the equations are symmetric across regions. 
Ricardian households in ‘Southern European countries’ maximize their intertemporal utility function

$$
U_{t}^{R H}=\mathbb{E}_{t} \sum_{k=0}^{\infty} \beta^{k}\left\{\log C_{t+k}^{R H}-\frac{\left(N_{t+k}^{R H}\right)^{1+\varnothing}}{1+\varnothing}\right\}
$$

where $\mathbb{E}_{t}$ is the expectations operator, $\beta$ is the discount factor, $C_{t}^{R H}$ is a consumption index, $N_{t}^{R H}$ is the household's labor supply and $1 / \varnothing$ is the Frisch elasticity of labor supply. As mentioned, non-Ricardian households do not intertemporally optimize their behavior. Instead they maximize their utility on a period-by-period basis. They maximize the utility function

$$
U_{t}^{N R}=\left\{\log C_{t}^{N R}-\frac{\left(N_{t}^{N R}\right)^{1+\varnothing}}{1+\varnothing}\right\}
$$

The consumption index of Ricardian households in 'Southern European countries' (non-Ricardian households have an identical consumption index) is ${ }^{4}$

$$
C_{t}^{R H}=\left\{(1-\omega)^{\frac{1}{\sigma}}\left(C_{t}^{S E}\right)^{\frac{\sigma-1}{\sigma}}+\omega^{\frac{1}{\sigma}}\left(C_{t}^{C N E}\right)^{\frac{\sigma-1}{\sigma}}\right\}^{\frac{\sigma}{1-\sigma}},
$$

where $C_{t}^{S E}$ and $C_{t}^{C N E}$ respectively denote the consumption by households in 'Southern European countries' of the 'Southern European countries" and the "Central-Northern European countries"' goods, $\sigma$ is the elasticity of substitution between the 'Southern European countries' and the 'CentralNorthern European countries' goods (cross-country substitutability, for short) and $\omega$ is the steady state share of imported goods in the consumption basket of the 'Southern European countries'.

The consumption of the 'Southern European countries'" and the 'Central-Northern European countries" goods $C_{t}^{S E}$ and $C_{t}^{C N E}$ are defined as

$$
C_{t}^{S E}=\left[(1-n)^{-\frac{1}{\epsilon}} \int_{n}^{1}\left(C_{t}^{S E}(i)\right)^{\frac{\epsilon-1}{\epsilon}} d i\right]^{\frac{\epsilon}{\epsilon-1}}, C_{t}^{C N E}=\left[n^{-\frac{1}{\epsilon}} \int_{0}^{n}\left(C_{t}^{C N E}(i)\right)^{\frac{\epsilon-1}{\epsilon}} d i\right]^{\frac{\epsilon}{\epsilon-1}},
$$

where $c_{t}^{S E}(i)$ and $c_{t}^{C N E}(i)$ respectively denote consumption, by households in 'Southern European countries', of the differentiated goods produced in the 'Southern European countries' and in the 'Central-Northern European countries' and $\epsilon$ is the elasticity of substitution between goods produced in the same region. We refer to $\epsilon$ as the within-country substitutability.

Given the consumption indexes, the 'Southern European countries"' demand for the representative good $i$ produced in 'Southern European countries' and in 'Central-Northern European countries' is

$$
\begin{gathered}
c_{t}^{S E}(i)=\frac{1-\omega}{1-n}\left(\frac{p_{t}^{S E}(i)}{P_{t}^{S E}}\right)^{-\epsilon}\left(\frac{P_{t}^{S E}}{P_{t}}\right)^{-\sigma} C_{t}, \\
c_{t}^{C N E}(i)=\frac{\omega}{n}\left(\frac{P_{t}^{C N E}(i)}{P_{t}^{C N E}}\right)^{-\epsilon}\left(\frac{P_{t}^{C N E}}{P_{t}}\right)^{-\sigma} C_{t},
\end{gathered}
$$

respectively, where $P_{t}^{S E}(i)$ is the price of the 'Southern European countries' $\operatorname{good} i, P_{t}^{C N E}(i)$ is the price of the "Central-Northern European countries" good $i$ and $C_{t}=\lambda C_{t}^{N R}+(1-\lambda) C_{t}^{R H}$ denotes the 'Southern European countries' aggregate consumption. $P_{t}^{S E}\left(P_{t}^{C N E}\right)$ is the price index corresponding to

${ }^{4}$ The Ricardian household in 'Central-Northern countries' has the following consumption index ('C
Northern countries' variables are denoted by an asterisk):
$C_{t}^{* R H}=\left\{\left(1-\omega^{*}\right)^{\frac{1}{\sigma}}\left(C_{t}^{* C N E}\right)^{\frac{\sigma-1}{\sigma}}+\left(\omega^{*}\right)^{\frac{1}{\sigma}}\left(C_{t}^{* S E}\right)^{\frac{\sigma-1}{\sigma}}\right\}^{\frac{\sigma}{1-\sigma}}$, where $\omega^{*}$ is the share of imported goods. 
the 'Southern European countries' ('Central-Northern European countries') consumption basket $C_{t}^{S E}$ $\left(C_{t}^{C N E}\right)$ and $P_{t}$ is the 'Southern European countries' price index. They are defined as follows:

$$
\begin{aligned}
& P_{t}^{S E}=\left((1-n)^{-1} \int_{n}^{1} P_{t}(i)^{1-\epsilon} d i\right)^{\frac{1}{1-\epsilon}}, \\
& P_{t}^{C N E}=\left(n^{-1} \int_{0}^{n} P_{t}^{C N E}(i)^{1-\epsilon} d i\right)^{\frac{1}{1-\epsilon}}, \\
& P_{t}=\left((1-\omega)\left(P_{t}^{S E}\right)^{1-\sigma}+\omega\left(P_{t}^{C N E}\right)^{1-\sigma}\right)^{\frac{1}{1-\sigma}} .
\end{aligned}
$$

The corresponding price indexes for the 'Central-Northern European countries' are defined analogously. For future reference, we define the 'Southern European countries' terms of trade, denoted by $S_{t}$, as the relative price of the 'Central-Northern European countries' goods in terms of the 'Southern European countries' goods.

$$
S_{t}=\frac{P_{t}^{C N E}}{P_{t}^{S E}}
$$

In addition, the consumer-price-index-based real exchange rate, denoted by $R E R$, is defined as

$$
R E R_{t}=\frac{P_{t}}{P_{t}^{*}}
$$

\subsubsection{Budget constraints and consumption decisions}

The budget constraint of the 'Southern European countries'’ Ricardian household is given by

$$
B_{t+1}+\left(1+\tau_{t}^{V A T}\right) P_{t} C_{t}^{R H}=R_{t-1} B_{t}+W_{t} N_{t}^{R H}+\Pi_{t}-T_{t} .
$$

$B_{t}$ denotes the holding of nominal bonds at the beginning of period t, $\tau_{t}^{V A T}$ is the VAT rate, $R_{t-1}$ is the gross return on bonds between $t-1$ and $t, W_{t}$ is the economy-wide nominal wage paid to the household, $\Pi_{t}$ denotes nominal profits of the 'Southern European countries' firms and $T_{t}$ denotes transfers from the government.

The optimal consumption of the Ricardian household is governed by the following Euler equations:

$$
\begin{aligned}
& R_{t}^{-1}=\beta \mathbb{E}_{t}\left\{\frac{C_{t}^{R H}}{C_{t+1}^{R H}} \frac{P_{t}}{P_{t+1}} \frac{1+\tau_{t}^{V A T}}{1+\tau_{t+1}^{V A T}}\right\}, \\
& \left(R_{t}^{*}\right)^{-1}=\beta \mathbb{E}_{t}\left\{\frac{C_{t}^{* R H}}{C_{t+1}^{* R H}} \frac{P_{t}^{*}}{P_{t+1}^{*}} \frac{1+\tau_{t}^{* V A T}}{1+\tau_{t+1}^{* V A T}}\right\} .
\end{aligned}
$$

A simple way to render the model stationary is to assume that the domestic interest rate is increasing in the level of net foreign debt (Schmitt-Grohe and Uribe 2003). We include a risk premium for the interest rate parity condition that forces external debt in the long term to return to the initial level. The interest parity condition with risk premium is given by

$$
R_{t}=R_{t}^{*}-\psi\left(\exp \left(B_{t}\right)-1\right),
$$

where $\psi\left(\exp \left(B_{t}\right)-1\right)$ is the risk premium.

The budget constraint of the 'Southern European countries' non-Ricardian household is given by

$$
\left(1+\tau_{t}^{V A T}\right) P_{t} C_{t}^{N R}=W_{t} N_{t}^{N R}-T_{t} .
$$

Therefore, the level of consumption of the non-Ricardian household is 


$$
C_{t}^{N R}=\frac{W_{t} N_{t}^{N R}}{\left(1+\tau_{t}^{V A T}\right) P_{t}}-\frac{T_{t}}{\left(1+\tau_{t}^{V A T}\right) P_{t}}
$$

\subsubsection{Aggregate demand and the trade balance}

Total demand for the 'Southern European countries' good $i$ is the sum of the demand in 'Southern European countries' and in 'Central-Northern European countries', as follows:

$$
Y_{t}(i)=\left(\frac{P_{t}(i)}{P_{t}^{S E}}\right)^{-\epsilon}\left[(1-\omega)\left(\frac{P_{t}^{S E}}{P_{t}}\right)^{-\sigma} C_{t}+\frac{n}{1-n} \omega^{*}\left(\frac{P_{t}^{S E}}{P_{t}^{*}}\right)^{-\sigma} C_{t}^{*}\right]
$$

Defining $Y_{t}^{S E} \equiv(1-\omega)\left(\frac{P_{t}^{S E}}{P_{t}}\right)^{-\sigma} C_{t}+\frac{n}{1-n} \omega^{*}\left(\frac{P_{t}^{S E}}{P_{t}^{*}}\right)^{-\sigma} C_{t}^{*}$ as total consumption of the bundle containing 'Southern European countries'” goods, we get the aggregate demand for good i:

$$
Y_{t}(i)=\left(\frac{P_{t}(i)}{P_{t}^{D C}}\right)^{-\epsilon} Y_{t}^{S E}
$$

One idea of a fiscal devaluation is to improve the trade balance. For future reference, we define the real trade balance (TB), expressed in terms of the domestic goods bundle, as follows:

$$
\frac{T B_{t}}{P_{t}^{S E}}=Y_{t}-\frac{P_{t}}{P_{t}^{S E}} C_{t}
$$

\subsubsection{Wage setting and employment}

Typical features of European labor markets are a strong influence of labor unions and sticky wages. We therefore assume imperfect competition in the labor market and sticky wages. Workers supply a differentiated and imperfectly substitutable input to firms. Workers delegate wage setting to typespecific labor unions that exploit the market power in wage setting. We assume that two types of households, Ricardian and non-Ricardian, do not differ with respect to their labor market characteristics. We assume that the marginal rate of substitution that unions take into account is a weighted average of both households' marginal rates of substitution between consumption and leisure. Although households can have different levels of consumption, both types work the same number of hours.

We introduce wage rigidities in the form of staggered nominal wage setting à la Calvo (1983). A labor union representing type $z$ workers may reset its wages in any given period with a probability $1-\theta_{w}$, independently of the amount of time since the last wage adjustment. Therefore, the labor union $z$ 's objective is given by

$$
\max _{t}(z) \sum_{k=0}^{\infty} \beta^{k} \theta_{w}^{k} \mathbb{E}_{t}\left\{\left(\frac{1-\lambda}{C_{t+k}^{R H}}+\frac{\lambda}{C_{t+k}^{N R}}\right) \frac{W_{t}(z)}{\left(1+\tau_{t}^{V A T}\right) P_{t+k}} N_{t+k \mid t}(z)-\frac{N_{t+k \mid t}^{1+\emptyset}(z)}{1+\emptyset}\right\},
$$

where $N_{t+k \mid t}(z)$ is the employment level of $z$ type workers in period $t+k$ and whose union is able to reset the type-specific wage rate $W_{t}(z)$ in period $t$. In setting wages, the labor union takes into account the firms' labor demand. Firm $i$ employs $N_{t}(i, z)$ hours of all labor types $z$ and aggregates them to the labor index $N_{t}(i)$ given by

$$
N_{t}(i)=\left[(1-n)^{-\frac{1}{\epsilon_{w}}} \int_{n}^{1} N(i, z)_{t}^{\frac{\epsilon_{w}-1}{\epsilon_{w}}} d z\right]^{\frac{\epsilon_{w}}{\epsilon_{w}-1}},
$$

where $\epsilon_{w}$ is the elasticity of substitution between different types of labor. Equation (7) is used to derive firm $i$ 's demand for labor-type $z$, to give 


$$
N_{t}(i, z)=\frac{1}{1-n}\left(\frac{W_{t}(z)}{W_{t}}\right)^{-\epsilon_{w}} N_{t}(i)
$$

where $W_{t}$ is the average wage level in 'Southern European countries', which is

$$
W_{t}=\left[\frac{1}{1-n} \int_{n}^{1}\left(W_{t}(z)\right)^{1-\epsilon_{w}} d z\right]^{\frac{1}{1-\epsilon_{w}}}
$$

Aggregation of the firm-specific demand functions over all firms yields the aggregate demand for labor type $\mathrm{z}$, as follows:

$$
\int_{n}^{1} N_{t}(i, z) d i \equiv N_{t}(z)=\left(\frac{W_{t}(z)}{W_{t}}\right)^{-\epsilon_{w}} \frac{1}{1-n} \int_{n}^{1} N(i)_{t} d i .
$$

The labor union maximizes equation (6) while taking into account equation (10). The first-order condition is

$$
\sum_{k=0}^{\infty} \beta^{k} \theta_{w}^{k} \mathbb{E}_{t}\left\{N(z)_{t+k \mid t}\left(\left(\frac{1-\lambda}{C_{t+k}^{R H}}+\frac{\lambda}{C_{t+k}^{N R}}\right) \frac{W_{t}^{O}}{\left(1+\tau_{t}^{V A T}\right) P_{t+k}}-\frac{\epsilon_{w}}{\epsilon_{w}-1}\left(N(z)_{t+k \mid t}\right)^{\emptyset}\right)\right\}=0
$$

where $W_{t}^{O}$ is the optimal wage set by unions that reset their wages in period $t$. In the optimum, the weighted average of the marginal utility of the real wage, which is implied by setting $W_{t}(z)$ today, equals the average marginal disutility from working an extra hour.

The structure of wage setting implies that in each period a fraction of labor unions, $1-\theta_{w}$, set a new wage, and the remaining fraction keep their wage unchanged. This implies that aggregate wage index is

$$
W_{t}=\left[\theta_{w}\left(W_{t-1}\right)^{1-\epsilon_{w}}+\left(1-\theta_{w}\right)\left(W_{t}^{O}\right)^{1-\epsilon_{w}}\right]^{\frac{1}{1-\epsilon_{w}}}
$$

Aggregate employment $N_{t}$ is the sum over all firms i and types of labor z, as follows

$$
N_{t} \equiv \frac{1}{1-n} \int_{n}^{1} \int_{n}^{1} N_{t}(i, z) d i d z .
$$

Employing the definitions of price-dispersion $s_{t}^{p} \equiv \frac{1}{1-n} \int_{n}^{1}\left(\frac{P_{t}(i)}{P_{t}^{S E}}\right)^{-\epsilon} d i \geq 1$ and wage-dispersion $s_{t}^{w} \equiv \frac{1}{1-n} \int_{n}^{1}\left(\frac{W_{t}(z)}{W_{t}}\right)^{-\epsilon_{w}} d z \geq 1$, as well as total demand for good i (equation (5)) and the linear production function introduced below (equation (11)), it can easily be shown that aggregate employment is governed by

$$
N_{t}=s_{t}^{p} s_{t}^{w} Y_{t}
$$

We see that in the presence of wage or price dispersion, one unit of consumption of the domestic bundle requires more than one unit of aggregate employment, due to inefficiencies caused by price and wage rigidities.

\subsection{Firms and price setting}

The production function of the typical firm $\mathrm{i}$ is

$$
Y_{t}(i)=N_{t}(i)
$$

where $Y_{t}(i)$ is firm i's output and $N_{t}(i)$ is firm i's effective employment (net of inefficiencies due to wage dispersion), specified in equation (7). 
We assume that the payroll tax is paid by the firm, and we refer to it as SCR. Firm i's profits are given by

$$
\Pi_{t}(i)=P_{t}^{S E}(i) Y_{t}(i)-\left(1+\tau_{t}^{S C R}\right) \int_{n}^{1} W_{t}(z) N_{t}(i, z) d z
$$

where $\tau_{t}^{S C R}$ is the SCR rate. Employing firm i's demand for labor-type z (equation (8)) and a wagedispersion index $s w_{t} \equiv \frac{1}{1-n} \int_{n}^{1}\left(\frac{W_{t}(z)}{W_{t}}\right)^{1-\epsilon_{w}} d z$, we can express profits as follows:

$$
\Pi_{t}(i)=P_{t}^{S E}(i) Y_{t}(i)-\left(1+\tau_{t}^{S C R}\right) s w_{t} W_{t} N_{t}(i)
$$

Wage dispersion $\left(s w_{t}>1\right)$ implies an inefficient allocation in the employment of different types of labor, which increases the total amount of labor required to produce a given amount of output. A higher wage bill lowers profits for a given amount of output.

We introduce price rigidities in the form of staggered price setting à la Calvo (1983). Each firm may reset its price with a probability $1-\theta_{p}$, independent of the time elapsed since last adjustment and independent of other firms. With Calvo pricing, firm $i$ seeks to maximize the discounted value of expected profits

$$
\underset{P_{t}(i)}{\max } \mathbb{E}_{t} \sum_{k=0}^{\infty} \theta_{p}^{k} Q_{t, t+k} \Pi_{t+k}(i)
$$

where $Q_{t, t+k} \equiv \beta^{k} \mathbb{E}_{t}\left\{\frac{C_{t}^{R H}}{C_{t+k}^{R H}} \frac{P_{t}}{P_{t+k}} \frac{1+\tau_{t}^{V A T}}{1+\tau_{t+k}^{V A T}}\right\}$ is a stochastic discount factor between period $t$ and period $t+k$. The first-order condition for the firm's maximization problem is

$$
\mathbb{E}_{t} \sum_{k=0}^{\infty} \theta_{p}^{k} Q_{t, t+k} Y_{t, t+k}\left[P_{t}^{O}-\frac{\epsilon}{\epsilon-1} M C_{t+k}\right]=0,
$$

where $P_{t}^{O}$ is the optimal price in period $t$ and $M C_{t}$ is the marginal cost, defined as

$$
M C_{t}=\left(1+\tau_{t}^{S C R}\right) W_{t} \frac{1}{1-n} \int_{n}^{1}\left(\frac{W_{t}(z)}{W_{t}}\right)^{1-\epsilon_{w}} d z
$$

Alternatively, using the definition of wage-dispersion, the marginal cost can be expressed as follows:

$$
M C_{t}=\left(1+\tau_{t}^{S C R}\right) s_{t}^{w} W_{t}
$$

The presence of wage-dispersion $\left(s_{t}^{w}>1\right)$ implies an inefficient usage of labor types. This increases the amount of labor required to produce an additional unit of output and thereby marginal costs.

\subsubsection{Aggregate prices and aggregate supply}

With Calvo pricing, the price index of the 'Southern European countries'” goods is

$$
P_{t}^{S E}=\left[\theta_{p}(1-n)^{-1} \int_{n}^{1}\left(P_{t-1}(i)\right)^{1-\epsilon} d i+\left(1-\theta_{p}\right)\left(P_{t}^{O}\right)^{1-\epsilon}\right]^{\frac{1}{1-\epsilon}}
$$

In equation (11) the integral contains only the prices of the 'Southern European countries'” goods whose prices are not allowed to be reset in period $t$. From the law of large numbers, for those firms, the average price $P_{t-1}^{S E}$ prevails and their mass equals $\theta_{p}$, so that the price index becomes

$$
P_{t}^{S E}=\left[\theta_{p}\left(P_{t-1}^{S E}\right)^{1-\epsilon}+\left(1-\theta_{p}\right)\left(P_{t}^{O}\right)^{1-\epsilon}\right]^{\frac{1}{1-\epsilon}}
$$

This equation and the FOC above jointly determine aggregate supply. 


\subsection{Fiscal and monetary policy}

We assume that all government spending is for public transfers to households, which can be financed through Value Added Taxes and employers' social contributions. We therefore abstract from government consumption. The budget constraint of the government is given by

$$
\tau_{t}^{V A T} C_{t}+\tau_{t}^{S C R} W_{t} N_{t}=T_{t} .
$$

The first part of the left side of the above equation is tax revenue from VAT taxation and the second part is SCR tax revenue.

We assume that the VAT and SCR tax rates follow AR(1) processes

$$
\begin{aligned}
& \tau_{t}^{V A T}=\rho^{V A T} \tau_{t-1}^{V A T}+\varepsilon_{t}^{V A T}, \\
& \tau_{t}^{S C R}=\rho^{S C R} \tau_{t-1}^{S C R}+\varepsilon_{t}^{S C R},
\end{aligned}
$$

where $\rho^{V A T}$ and $\rho^{S C R} \in[0,1]$ and $\varepsilon_{t}^{V A T}$ and $\varepsilon_{t}^{S C R}$ are zero mean white-noise processes that represent unexpected changes to tax rates.

We assume that the central bank of the euro area follows a Taylor-type interest rate rule. The central bank responds to euro area inflation, which is the population-weighted average of domestic inflation. Lipinska and von Thadden (2012) show that the short-term effects of a shift in taxation depend on whether the monetary policy rule is specified in terms of pre-tax or after-tax consumer price inflation. We believe that it is reasonable to assume-in the current economic situation-that the central bank would not react to the 'Southern European countries' one-off inflation caused by an increase in the VAT rate. The interest rate of the euro area, denoted by $R_{t}^{U}$, is determined by the following monetary policy rule

$$
R_{t}^{U}=\beta^{-1}\left(\left(\frac{P_{t}^{S E}}{P_{t-1}^{S E}}\right)^{1-n}\left(\frac{P_{t}^{C N E}}{P_{t-1}^{C N E}}\right)^{n}\right)^{\alpha_{\pi}}
$$

where the coefficient $\alpha_{\pi}$ is non-negative and chosen by the central bank.

\section{Parameter values}

The parameterization of the model, summarized in Table 1 , is chosen to match the features of the 'Southern European countries' and the 'Central-Northern European countries'. The model, however, is solved around the steady state, where initial net foreign assets are zero. Periods are interpreted as quarters and the discount factor is set to 0.99. The relative size of the 'Southern European countries', $1-n$, is set to match the relative GDPs of the regions. According to the World Bank (2013), the relative size of the 'Southern European countries' in 2011 was 0.34 . We therefore set $1-n=0.34$. The share of Ricardian households, $1-\lambda$, is set to 0.5, based on Mankiw and Campbell (1990). The labor supply parameter, $\varnothing$, is set to one. This implies that the Frisch elasticity of labor supply is one, a value consistent with Kimball and Shapiro (2008). The coefficient $\left(\alpha_{\pi}\right)$ in the monetary policy rule is set to 1.5, based on Taylor (1993). The risk premium in the interest rate parity $(\psi)$ is set to 0.0038 , based on Bergin (2006).

We set the elasticity of substitution between goods produced in the same region $\epsilon$ to 9, implying a steady state price markup of 12.5 percent. Our chosen value is in the middle of the 6 to 11 range 
typically used in the literature. In addition, this value is often used in the New Keynesian literature, such as by Gali (2011), for example.

In the business cycle literature, a wide range of values for the elasticity of substitution between different types of labor $\left(\epsilon_{w}\right)$ has been used. For example, Adolfson et al. (2007) use the value 21 in a model calibrated for the euro area, Kormilitsina and Nekipelov (2012) use 6 and Coenen et al. (2010) use 3. We set the parameter to 9, which is near the middle of the range used in the literature. This parameterization implies that the elasticity of substitution between different types of labor is equal to the elasticity of substitution between goods produced in the same region.

Cross-country substitutability, the elasticity of substitution between the 'Southern European countries' and the 'Central-Northern European countries' goods $(\sigma)$, is a key parameter, because it affects the strength of the expenditure-switching effect. The empirical literature shows a wide range of estimates for it. Feenstra et al. (2012) find that the micro elasticity (substitution between different import suppliers) between domestic and foreign goods is 3 , whereas the macro elasticity (substitution between domestic production and imports) does not significantly differ from unity. We set crosscountry substitutability to 2 , which is an average of these estimates.

The share of imported goods in the 'Southern European countries' consumption basket, $\omega$, is set to match these countries' GDP-weighted import-to-GDP ratio. Our calculation, using the World Bank data (World Bank 2013), shows that the ratio is 33 percent, so $\omega$ is set to 0.33 . We assume that the per-capita levels of output and consumption are identical across regions. This requires that $\omega^{*}=$ $\omega(1-n / n)$ so that the implied share of imported goods in 'Central-Northern European countries' consumption basket $\left(\omega^{*}\right)$ is 17 percent.

Kemmerling (2009) calculates effective SCR and VAT tax rates for euro area countries (excluding Luxembourg). Our calculation shows that the GDP-weighted average for the VAT (SCR) rate in the euro area (excluding Luxembourg) is 16 percent (24 percent) We, therefore, set the VAT rate to 16 percent and the SCR rate to 24 percent. In comparison, Lipinska and von Thadden (2012) set the VAT rate to 15 percent, based on nominal consumption tax rates in the euro area.

Wage and price rigidities are key variables in determining the adjustment of the two economies to a fiscal devaluation. Druant et al. (2009) analyze wage and price adjustment in ten euro-area countries and find that the average duration of wages (excluding Italy) is roughly one year. We match this figure by setting the Calvo parameter for wages $\left(\theta_{w}\right)$ to 0.75 . Druant et al. (2009) find that prices are adjusted more frequently than wages. In ten euro-area countries the average duration of prices is 9.6 months. We set the Calvo parameter for prices $\left(\theta_{p}\right)$ to 0.66 , which implies an average duration between price adjustments of nine months.

Parameters $\left(\rho^{V A T}, \rho^{S C R}\right)$ that govern the persistence of the 'Southern European countries' tax shocks are set to 0.999999 ('Central-Northern European countries' keep their tax rates unchanged). This implies that tax shocks are virtually permanent. ${ }^{5}$ We consider a revenue-neutral shift from SCR towards VAT. The sizes of tax shocks $\left(\varepsilon_{t}^{V A T}, \varepsilon_{t}^{S C R}\right)$ in the 'Southern European countries' are set such that the VAT revenue is increased by 1 percent of ex post GDP, while SCR revenue is reduced by 1 percent of ex post GDP.

\footnotetext{
5 To check the validity of this approach, we compared the convergent impulse responses with the steady state that would result from the new tax rates.
} 
Table 1: Parameterization of the model

\begin{tabular}{|c|c|c|}
\hline Parameter & Value & Description \\
\hline$\beta$ & 0.99 & Discount factor \\
\hline $1-n$ & 0.34 & $\begin{array}{l}\text { Relative size of the 'Southern } \\
\text { European countries' }\end{array}$ \\
\hline $1-\lambda$ & 0.5 & Share of Ricardian households \\
\hline$\varnothing$ & 1 & Labor supply parameter \\
\hline$\epsilon$ & 9 & $\begin{array}{l}\text { Elasticity of substitution between } \\
\text { goods within regions }\end{array}$ \\
\hline$\sigma$ & 2 & Cross-country substitutability \\
\hline$\omega$ & 0.33 & $\begin{array}{l}\text { Share of imported goods in the } \\
\text { 'Southern European countries' } \\
\text { consumption basket }\end{array}$ \\
\hline$\omega^{*}$ & 0.17 & $\begin{array}{l}\text { Share of imported goods in the } \\
\text { 'Central-Northern European } \\
\text { countries' consumption basket }\end{array}$ \\
\hline$\tau^{V A T}, \tau^{* V A T}$ & 0.16 & VAT rate \\
\hline$\tau^{S C R}, \tau^{* S C R}$ & 0.24 & SCR rate \\
\hline$\alpha_{\pi}$ & 1.5 & $\begin{array}{l}\text { Coefficient in the monetary policy } \\
\text { rule }\end{array}$ \\
\hline$\psi$ & 0.0038 & Risk premium \\
\hline$\epsilon_{w}$ & 9 & $\begin{array}{c}\text { Elasticity of substitution between } \\
\text { different types of labor }\end{array}$ \\
\hline$\theta_{p}$ & 0.66 & Degree of price stickiness \\
\hline$\theta_{w}$ & 0.75 & Degree of wage stickiness \\
\hline$\rho^{V A T}, \rho^{S C R}$ & 0.999999 & Persistence of tax shocks \\
\hline
\end{tabular}

\section{International effects of a fiscal devaluation in 'Southern European countries'}

In this section, we analyze the international transmission of a fiscal devaluation in 'Southern European countries'. We model a fiscal devaluation as a shift from SCR to VAT equivalent of 1 percent of ex post GDP. Our parameterization implies that, in order to achieve a shift of this magnitude, the VAT rate needs to be increased by 1 percentage point, whereas the SCR rate needs to be reduced by 1.7 percentage points. We solve the model by using a perturbation method based on a second-order accurate approximation of the system of equations.

The response of the main macroeconomic variables to the fiscal devaluation is shown in Figure 3 below. In Figures 3 and 4, the horizontal axis denotes time. The vertical axis typically shows percentage deviations from the initial steady state. However, the change in bond holdings, whose initial steady state is zero, is expressed as a deviation from initial GDP. In addition, the responses of inflation and interest rates are expressed as basis point deviations in annual terms. 
Figure 3: Dynamic effects of a fiscal devaluation
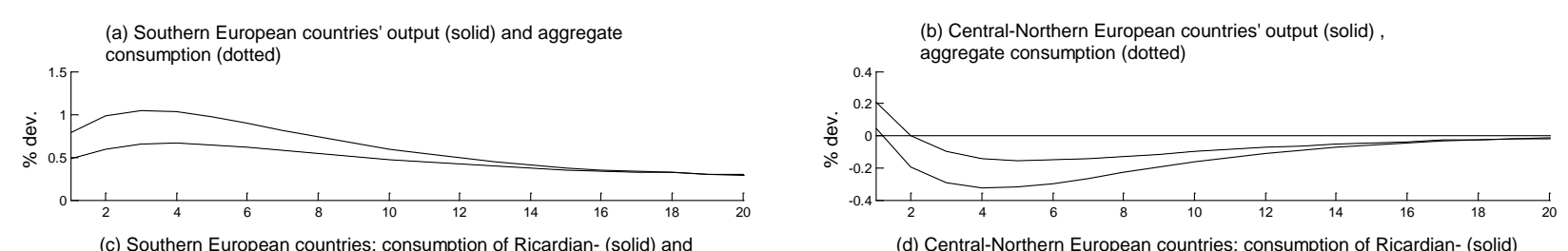

(c) Southern European countries: consumption of Ricardian- (solid) and

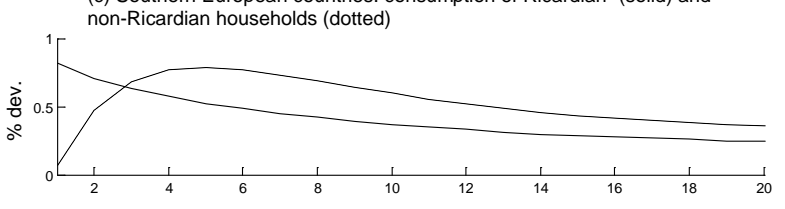

(d) Central-Northern European countries: consumption of Ricardian- (solid)

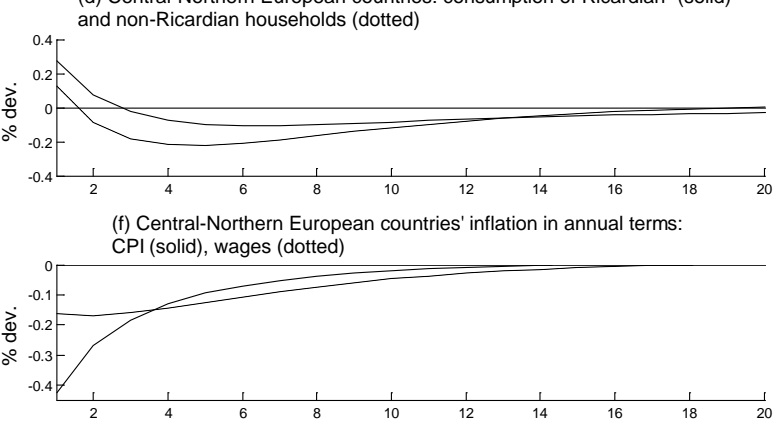

(e) Southern European countries' inflation in annual terms: CPI (solid), wages (dotted)

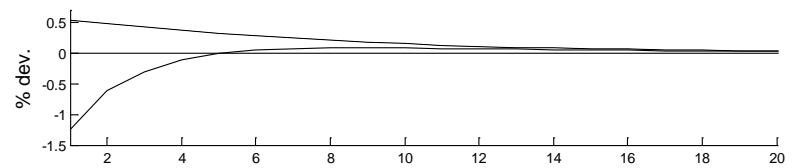

(g) Trade balance in Southern European countries (solid) and Central-Northern European countries (dotted)

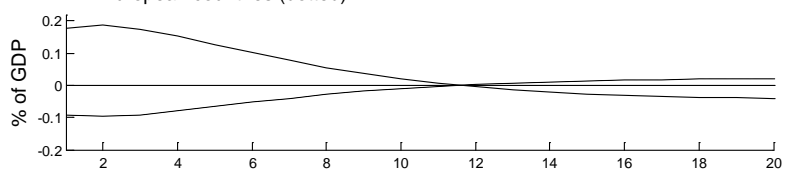

(i) Union-wide policy rate in annual terms (solid), real interest rates in Southern
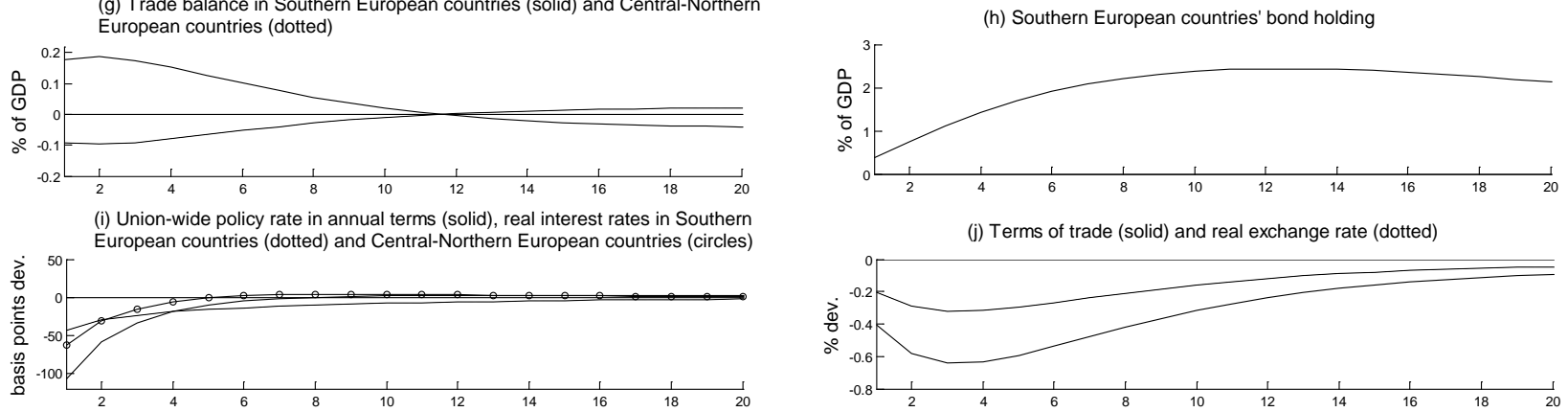

(j) Terms of trade (solid) and real exchange rate (dotted)

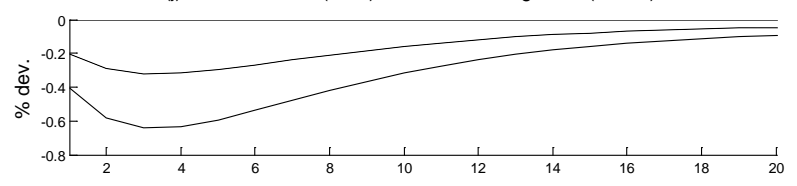

Figure 3 emphasizes that a reduction in the SCR rate in 'Southern European countries' implies a fiscal devaluation, which on impact lowers the relative price of the 'Southern European countries' (a terms of trade deterioration for 'Southern European countries'). The channel through which this terms-oftrade deterioration comes about is that the reduction in SCR lowers marginal costs for 'Southern European countries' firms, thus reducing producer prices.

The other component of the fiscal reform, the increase in the VAT rate in 'Southern European countries', pushes consumer prices up, offsetting the reduction in producer prices. However, the VAT increases the consumer price of the 'Central-Northern European countries' goods as well as of those of 'Southern European countries', while the reduction in SCR only reduces 'Southern European countries' prices. This mechanism is the essence of the fiscal devaluation, and results in lower relative prices of 'Southern European countries' goods, which, under a fixed nominal exchange rate, is equivalent to a real exchange rate devaluation.

The terms of trade deterioration and the corresponding real exchange rate depreciation for 'Southern European countries' implies a shift of euro area demand away from 'Central-Northern European countries' goods and towards 'Southern European countries' goods. This expenditure switching effect increases 'Southern European countries' output (employment) and decreases 'Central-Northern European countries' output (employment) in the short term. 
Due to the Calvo-pricing mechanism at work in the model, however, only a fraction of firms can lower prices on impact following the SCR reduction. After a few quarters, however, a larger fraction of the 'Southern European countries' firms become able to lower their prices. This implies that the expenditure switching effect becomes even stronger after a few quarters, pushing 'Southern European countries' output further up. As Figure 3 shows, the fiscal devaluation increases 'Southern European countries' output by 0.8 percent in the first quarter, while the peak impact is 1.04 percent in the third quarter.

However, the positive effect of the fiscal devaluation on 'Southern European countries' output through the expenditure switching effect is mitigated by the wage-price dynamics. As shown in Figure 3(e), immediately after the fiscal devaluation, wages start to adjust upwards in 'Southern European countries'. This happens because the increase in consumption prices, caused by the increase in the VAT rate, pushes labor unions to require higher nominal wages. As a consequence, real marginal costs in 'Southern European countries', which had fallen on impact due to the reduction in the SCR rate, start to adjust toward the original, pre-reform level. This has a negative effect on output in 'Southern European countries', which gradually offsets the positive impact of the expenditure switching effect discussed above. As a consequence of the various effects discussed above, output in 'Southern European countries' displays a hump shaped response to a fiscal devaluation in these countries, and the tax reform still has a small positive effect on output, even in the long term.

Looking at the international transmission effects of fiscal devaluations, Figure 3 shows that-despite the expenditure switching effect, which makes 'Southern European countries' more competitive'Central-Northern European countries' output increases immediately after the reform fiscal devaluation, despite the expenditure switching effect. This result is due to the interaction between fiscal and monetary policy. As Figure 3 shows, following the fiscal devaluation, both 'Southern European countries' and 'Central-Northern European countries' experience deflation. For the former, this is due to the reduction in the SCR rate; for the latter, reduced demand for their goods. Since the euro area central bank is assumed to set monetary policy according to a Taylor rule, it reacts to deflation by cutting policy interest rates. This implies that the real interest rate falls in 'CentralNorthern European countries' (Figure 3(f)), offsetting the negative impact on output of the expenditure switching effect. On impact, the positive effect of the monetary policy expansion dominates the negative one due to the expenditure switching effect, and 'Central-Northern European countries' output slightly increases. In the medium to long term, however, as a larger fraction of firms in 'Southern European countries' become able to lower their prices, the expenditure switching effect dominates and 'Central-Northern European countries' output falls. In the trough, the effect on 'Central-Northern European countries' output is -0.33 percent in the fourth quarter after the fiscal devaluation. After that, as inflation in 'Southern European countries' and the real exchange rate stabilize, the expenditure switching effect peters out, and output in 'Central-Northern European countries' slowly adjusts back to its pre-shock level.

In terms of effects on the external position, Figure 3 shows that in 'Southern European countries' both output and consumption increase following the fiscal devaluation. However, the increase in consumption is smaller than that of output, due to the deterioration in the terms of trade of the 'Southern European countries'. As a consequence, Ricardian households in 'Southern European countries' save a fraction of their increased income, leading to an improvement in the trade balance by about 0.19 percent of GDP, and to an accumulation of net foreign assets by 'Southern European countries', which at its peak amounts to more than 2 percent of GDP. 
However, the risk premium in the interest rate parity equation forces bond holdings of 'Southern European countries' to revert towards their initial level in the long term. In the medium term, Ricardian households in 'Southern European countries' start using their accumulated wealth to finance consumption. As a consequence, the 'Southern European countries' trade balance turns negative twelve quarters after the fiscal devaluation, and bond holdings of 'Southern European countries’ start declining, slowly reverting back to their pre-shock level.

Our results suggest that a fiscal devaluation could be used as a part of a policy package aimed at increasing output in 'Southern European countries' and balancing the euro area economy. In particular, Figure 3 shows that the positive impact on the output and consumption of 'Southern European countries' is larger than the negative impact on output and consumption of 'CentralNorthern European countries'. In addition, the former is permanent, in the sense that even in the long term a small positive effect persists, whereas the latter is temporary, since 'Central-Northern European countries' output and consumption revert back to their initial level.

Our results therefore lend some support to the argument—made, for example, by IMF (2011) — that fiscal devaluations should not be seen primarily as a form of tax competition, but that they might entail a structural improvement. Arnold et al. (2008) have stressed that the shift from labor taxes to consumption taxes can increase the level of GDP in the long term, because consumption taxes are less distortive taxes in terms of discouraging work, compared to labor taxes. From this point of view, a fiscal devaluation carried out in a monetary union entails benefits for the countries who implement it (by making their goods more competitive) but also for the union as a whole, by shifting the tax system in the union towards a less distortive one. In addition, our model has also shown that fiscal devaluations can provide additional benefits for the monetary union through fiscal-monetary policy interaction, because the central bank reacts to the deflation in the euro area caused by the fiscal devaluation by cutting interest rates, which stimulates demand not only for the 'Southern European countries' who carried out the fiscal devaluation, but also for 'Central-Northern European countries'.

Our results however suggest that a fiscal devaluation is not an effective means for addressing the divergence in competitiveness and the current account imbalance between 'Central-Northern European countries' and 'Southern European countries'. In our model, a fiscal devaluation of roughly 6 percent of GDP is needed to correct-temporarily - the 1 percent trade balance deficit in 'Southern European countries'. A fiscal devaluation of 6 percent of GDP implies that the VAT rate needs to be increased by 6 percentage points. VAT rates are already quite high in 'Southern European countries' (see e.g. de Mooij and Keen 2013) and it may be difficult to raise them by such a large amount quickly. In addition, a fiscal devaluation of this size depreciates the real exchange rate of 'Southern European countries' only by 1.9 percent. Therefore we would like to point out that the divergence in competitiveness is best addressed through structural reforms, because the benefits of a fiscal devaluation on competitiveness are small relative to the size of the problem. Embarking on an experiment of a fiscal devaluation could lead to a delay of necessary reforms. Overall, our findings indicate that it might be misleading to suggest that significant gains in competitiveness and net trade can be expected through a fiscal devaluation.

De Mooij and Keen (2013) emphasize that there is almost no empirical evidence on trade impacts of tax reforms or fiscal devaluations. Franco (2011) analyzes the effects of changes of VAT and SCR on real exports and imports in Portugal using a VAR methodology. His findings support both the 
feasibility and the effectiveness of fiscal devaluations. ${ }^{6}$ In particular, he finds that a positive one standard deviation VAT shock decreases real imports by 3.4 percent, while a negative one standard deviation SCR shock increases real exports by 4.4 percent.

De Mooij and Keen (2013) carry out a similar analysis using a panel of OECD countries. They find that, for euro area countries, a shift of 1 percent of GDP from SCR to VAT would increase net exports by about 0.9-4 percent of GDP, depending on the specification of the model. The estimate is smaller and statistically insignificant for countries outside the euro area. Their result, however, suggests that, within the euro area, whereas a fiscal devaluation might increase the trade balance quite sizably in the short term, the effects eventually disappear in the medium to long term. There seems to be a wide gap between our results (and all other theoretical results) and those of de Mooij and Keen (2013). Their empirical results, however, imply that a raising the VAT rate by 1 percentage points and reducing the SCR rate by 1.7-the same policy that we calibrate in our model to achieve a 1 percent of GDP redistribution in taxation in 'Southern European countries'-improves net exports by 0.4 percent of GDP. ${ }^{7}$ The results of our paper are broadly consistent with these empirical estimates regarding the effect on the trade balance. In our model, under the benchmark parameterization, the trade balance of 'Southern European countries' improves by 0.18 percent of GDP, a weaker impact than the one found by de Mooij and Keen (2013). Consistent with the empirical evidence, we also find that the effect on the trade balance eventually disappears.

Farhi et al. (2013) use a new Keynesian two-country DSGE model to show that, even in the case of fixed exchange rates, fiscal policy can replicate the resource allocation attained under a nominal exchange rate devaluation. In particular, they find that two kinds of fiscal policy reforms can be equivalent to an exchange rate devaluation: a uniform increase in import tariff and export subsidy, and a VAT increase and a uniform SCR reduction. However, they do not use their two-country framework to analyze the international transmission of a fiscal devaluation, as we do.

Most previous papers have looked at these issues using small open economy models. A study by the Bank of Portugal (2011) looks at the impact of a balanced-budget tax policy reform aimed at increasing the external competitiveness, using a small open economy model calibrated to the Portuguese economy. The reform consists of a 1 percent of GDP reduction in SCR offset by an increase in consumption taxes. The result shows that the fiscal devaluation brings about a permanent real exchange rate depreciation of about 0.3 percent, which results in a permanent increase in output of about 0.6 percent, with the current account increasing on impact by 0.6 percent.

The European Central Bank (2012) uses three different multi-country models - the National Institute Global Econometric Model (NiGEM), the New Multi-Country Model (NMCM) and the Euro Area and Global Economy (EAGLE) model - to analyze the effects of a fiscal devaluation in an individual country of the euro area, which can be considered a small open economy compared to the rest of the union. Their study finds that a fiscal devaluation—defined as an ex ante revenue-neutral 1 percent of GDP cut in SCR offset by a rise in VAT over five years-implies a hump-shaped response in output, with almost no effect on impact but a peak effect in the range of 0.2-0.5 percent after 6-9 quarters. The effect on the current account is also negligible on impact, and the peak effect is in the 0.1-0.5

\footnotetext{
6 Ivanova (2012), on the other hand, finds that reducing taxes on labor may actually worsen the current account balance.

7 De Mooij and Keen's (2013) estimates, using statutory tax rates, show that a 1 percentage point increase of the VAT (SCR) rate increases (reduces) net exports by $0.23(0.11)$ percent. These estimates imply that raising the VAT rate by 1 percentage points and reducing the SCR rate by 1.7 percentage points improves net exports of $(-0.11 \times-1.7)+(0.23 \times 1)=0.417$ percent of GDP.
} 
range. We find a much stronger effect on output in the short term, whereas the trade impact is in the range of the findings of the ECB.

Lipinska and von Thadden (2012) analyze fiscal devaluation using New Keynesian two-country model of a monetary union. Their model, therefore, is most directly related to ours. Lipinska and von Thadden (2012) find that the effectiveness of a fiscal devaluation depends on the degree of financial integration between the two countries. They, however, find that in a region whose size is half of a monetary union fiscal devaluations tend to be ineffective. They increase domestic output by only 0.05-0.15 percent, compared to 1 percent in our model. In addition, the spillover effect on foreign output is also very small.

Our results, that a fiscal policy is effective in terms of stimulating domestic output and that the international spillover effect is not negligible, are in contrast with those of Lipinska and von Thadden (2012). The difference between our results and theirs can be-partly-explained by different types of shocks. In Lipinska and von Thadden (2012) fiscal devaluation is a permanent increase in VAT by 1 percentage point and the additional VAT revenues are used to reduce the labor income tax such that the home country's long-term level of real government debt stays unchanged. As such, this is not a "pure" fiscal devaluation, because a reduction in the labor income tax does not necessarily imply large competitiveness gains for domestic goods, unlike a reduction in SCR. This is because-for given nominal wages and given pre-tax consumer prices-the increase in the VAT reduces real wages, while the reduction in the labor income tax rate increases them. The two effects thus work in opposite directions in their effect on the after-tax real wage. It follows, ceteris paribus, that the change in the equilibrium pre-tax nominal wage, which is relevant for the marginal costs and hence for pricesetting, is small. When wages are set in a staggering fashion the effect on marginal costs is even lower. In contrast, a reduction in the SCR directly reduces marginal costs, which is the key difference to a change in the labor income tax rate. For constant nominal wages and consumer prices, the tax reform implies a reduction in workers' real wages (due to the VAT increase), and a decline in marginal costs (due to the SCR decrease). This effect would have been absent if wages had been flexible. However, when nominal wages are set in a staggered fashion, the effect prevails long enough for prices to decline as a reaction to lower marginal costs. We show in section 4.1 that the effectiveness of the fiscal devaluation is significantly muted when wages are flexible. One of our key findings is therefore to find support for the results that a fiscal devaluation, if properly modeled as a reduction in SCRs, can substantially increase output in 'Southern European countries', thus helping to rebalance the euro area economy.

Lipinska and von Thadden (2012) assume that governments balance their real budgets every period by adjusting labor tax rates every period. We assume that that all government spending is for public transfers to households and that a fiscal devaluation is revenue neutral in the long term. In our model, public transfers in 'Southern European countries' increase very mildly in the short term. This implies that our finding that a fiscal devaluation is effective in the short term does not come from lower distortionary taxes that are financed by lump sum taxes or debt in the short term.

As further discussed in section 4.1, the use of different parameter values can explain part of the difference between our results and those of Lipinska and von Thadden (2012). ${ }^{8}$ For example, we set

\footnotetext{
8 In addition, part of the difference in results between our results and those of Lipinska and von Thadden (2012) can be explained by different solution methods. Lipinska and von Thadden (2012) use a first-order approximation, which ignores the cross term, i.e. the change in the tax-base times the change in the tax rate. The use of the second-order approximation, in our model, increases the effect of fiscal devaluation on 'Southern European countries' output in the short term by 10 percent.
} 
the cross-country substitutability to 2, whereas Lipinska and von Thadden (2012) set it to 1.5. A higher cross-country substitutability implies that the expenditure switching effect, which increases 'Southern European countries' output and decreases 'Central-Northern European countries' output in the short term, is higher in our model.

\subsection{Sensitivity analysis}

In this section, we analyze how sensitive the effects of a fiscal devaluation on the main variables are to changes in key parameter values. Figure 4 and Table 2 show the consequences of varying parameter values.

\section{Figure 4: Effects of varying key parameter values}

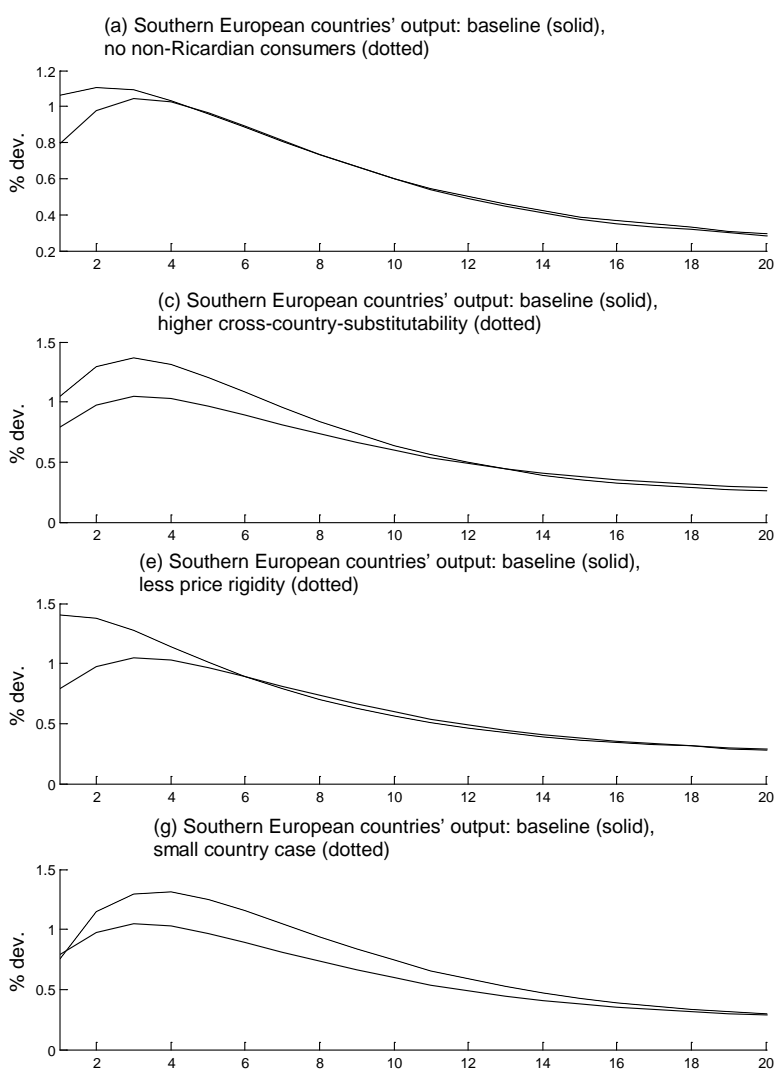

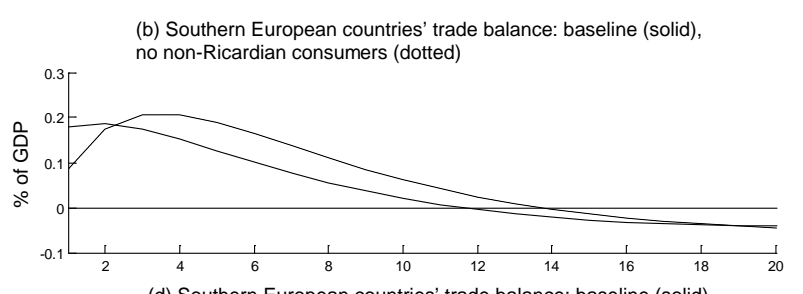

(d) Southern European countries' trade balance: baseline (solid)

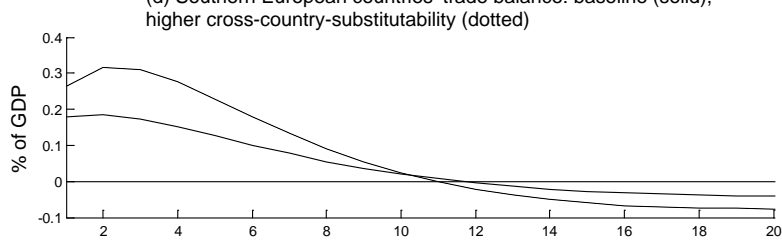

(f) Southern European countries' trade balance: baseline (solid), less price rigidity (dotted)

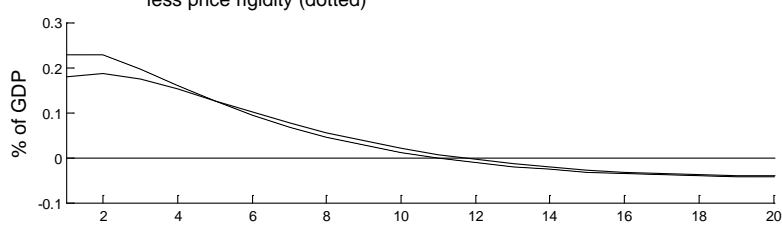

(h) Southern European countries' trade balance: baseline (solid), small country case (dotted)

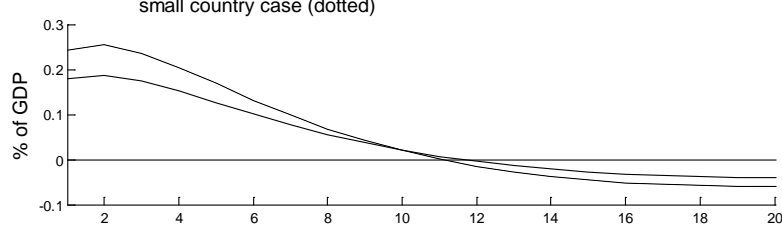

Figure 4(a) and rows 1 and 2 of Table 2 show that the effect of a fiscal devaluation on output is weaker in the short term, when the share of non-Ricardian households is zero $\left(\lambda=\lambda^{*}=0\right)$. NonRicardian households consume their current labor income in each period. The rise in nominal wages, the fall of prices and the increase in employment (see Figures 3(a) and 3(e)) that last for several quarters dominate the income reducing effect of the increase in the VAT. Non-Ricardian households' real income and consumption increase for five quarters after the change in taxes. The initial increase in consumption, however, is relatively muted when compared with the Ricardian households, as Figure 3(c) illustrates. The reason is that the increase in income evolves slowly due to the staggering price and wage changes. A conclusion is that the short-term effectiveness of a fiscal devaluation is weakened by the presence of non-Ricardian households when prices and wages need time to adjust. Our finding is consistent with Bosca et al. (2012) who find that when the share of Ricardian consumers gets smaller, the output effect of a fiscal devaluation becomes weaker. 
Empirical estimates on cross-country substitutability vary and the international economics literature uses a wide range of parameter values for it. Broda and Weinstein (2006) find that the median estimate of cross-country substitutability ranges between 2.3 and 3.7. Based on these estimates, we change it from 2 to 3. Row 3 of Table 2 and Figures 4(c)-4(d) show that the higher the cross-country substitutability, the higher the output and trade balance effect of a fiscal devaluation. The fact that 'Southern European countries' and 'Central-Northern European countries' goods are now better substitutes implies that the expenditure switching effect is stronger. This increases 'Southern European countries' output and decreases 'Central-Northern European countries', when compared with the benchmark case. A higher increase in 'Southern European countries' output means that their Ricardian households have more extra income in the short term. Consequently, the accumulation of international assets becomes stronger and the effect of a fiscal devaluation on the trade balance increases strongly.

Table 2: Consequences of varying key parameter values

\begin{tabular}{|c|c|c|c|c|c|}
\hline Row & Parameters & $\begin{array}{c}\text { Peak effect on } \\
\text { 'Southern } \\
\text { European } \\
\text { countries' } \\
\text { output }\end{array}$ & $\begin{array}{c}\text { Peak effect on } \\
\text { 'Central- } \\
\text { Northern } \\
\text { European } \\
\text { countries' output }\end{array}$ & $\begin{array}{c}\text { Peak effect on } \\
\text { 'Southern } \\
\text { European } \\
\text { countries' trade } \\
\text { balance }\end{array}$ & $\begin{array}{c}\text { Peak effect on } \\
\text { 'Central-Northern } \\
\text { European } \\
\text { countries' trade } \\
\text { balance }\end{array}$ \\
\hline 1 & Benchmark & $\begin{array}{c}+1.0 \% \\
\text { (deviation from } \\
\text { the initial EQ) }\end{array}$ & $-0.33 \%$ & $\begin{array}{c}+0.19 \% \text { of } \\
\text { current GDP }\end{array}$ & $-0.097 \%$ \\
\hline 2 & $\lambda=\lambda^{*}=0$ & $+1.1 \%$ & $-0.29 \%$ & $+0.21 \%$ & $-0.11 \%$ \\
\hline 3 & $\sigma=3$ & $+1.4 \%$ & $-0.46 \%$ & $+0.32 \%$ & $-0.167 \%$ \\
\hline 4 & $\sigma=1.5$ & $+0.86 \%$ & $-0.24 \%$ & $+0.14 \%$ & $-0.073 \%$ \\
\hline 5 & $\theta_{p}=0.5$ & $+1.4 \%$ & $-0.42 \%$ & $+0.23 \%$ & $-0.12 \%$ \\
\hline 6 & $1-n=0.05$ & $+1.3 \%$ & $-0.047 \%$ & $+0.25 \%$ & $-0.013 \%$ \\
\hline 7 & $\omega=0.25$ & $+1.0 \%$ & $-0.32 \%$ & $+0.17 \%$ & $-0.086 \%$ \\
\hline 8 & $\varnothing=2.5$ & $+1.0 \%$ & $-0.37 \%$ & $+0.19 \%$ & $-0.10 \%$ \\
\hline 9 & $\theta_{w}=0.01$ & $+0.25 \%$ & $+0.015 \%$ & $+0.061 \%$ & $-0.032 \%$ \\
\hline 10 & $\begin{array}{c}\text { Labor income } \\
\text { tax, instead of }\end{array}$ & $+0.29 \%$ & $+0.070 \%$ & $-0.029 \%$ & $+0.015 \%$ \\
\hline
\end{tabular}

The earlier literature has found that the output effects of a fiscal devaluation are robust to changes in the value of cross-country substitutability. European Commission (2006) finds that raising it from 2 to 5 increases the effect of a fiscal devaluation, in which labor income taxation is cut, on long-term output only from 0.2 to 0.24 in Germany. However, cross-country substitutability-most of allgoverns the strength of the expenditure switching effect in the short term. The long-term focus is 
therefore somewhat misleading. Bosca et al. (2012), however, find that even short-term output effects are robust to values of cross-country substitutability. They show that doubling the cross-country substitutability has virtually no impact on accumulated GDP after two years in Spain. In this paper, we show that the effects of a fiscal devaluation on output are more sensitive to the value of crosscountry substitutability than the earlier literature has found.

Row 4 of Table 3 shows the effects of a fiscal devaluation in a case where cross-country substitutability is set to 1.5, as in Lipinska and von Thadden (2012). A low cross-country substitutability implies a weaker expenditure switching effect. Therefore, the increase in 'Southern European countries' output becomes weaker. We, however, still find a much stronger effect on output than Lipinska and von Thadden (2012).

СРВ (2013) finds that the trade balance effects of a fiscal devaluation are robust to values to crosscountry substitutability. Doubling cross-country substitutability has minor quantitative impact on the trade balance. In our model, however, doubling cross-country substitutability from 1.5 to 3 increases the peak effect of a fiscal devaluation on the 'Southern European countries' trade balance by roughly 60 percent. We can therefore conclude that the effect of a fiscal devaluation on the trade balance is more sensitive to the value of cross-country substitutability than the earlier literature has found.

Figures 4(e) and 4(f) and row 5 of Table 2 show the consequences of varying the degree of price rigidity. In an alternative setup, we set the price rigidity parameter to 0.5 , implying an average delay of six months between price adjustments. This is consistent with the estimates of Bils and Klenow (2004). In this case, prices are more flexible. In the short term, a larger fraction of firms has an opportunity to lower prices and take the cost advantage of a reduction of the SCR rate. In the short term, a fiscal devaluation lowers the relative price of 'Southern European countries' goods by more than under the benchmark parameterization. Therefore, a stronger expenditure-switching effect explains a stronger increase of 'Southern European countries' output in the short term. The policy implication of this is that goods market reforms that foster price flexibility render fiscal devaluations more effective. On the other hand, as prices are more flexible, the expenditure switching effect fades away faster than under the benchmark parameterization.

The next step is to investigate the role of the country size. CPB (2013) argues that improving the competitiveness by a fiscal devaluation in one country happens at the expense of the competitiveness of another country. The beneficial effects on the trade balance get smaller if a fiscal devaluation is carried out in several countries at the same time. We analyze the small-country case by setting the relative size of the country that carries out fiscal devaluation to 5 percent $(1-n=0.05)$. The assumption that the per-capita level of output and consumption is identical across regions implies that the share of imported goods in the rest of the euro area must be changed to $1.7\left(\omega^{*}=0.017\right)$.

Figures 4(g), 4(h) and row 6 of Table 2 show that a fiscal devaluation carried out in a small country increases the domestic output by more than in the benchmark case. This finding is consistent with that of CPB (2013). CPB (2013) finds that the unilateral implementation of a fiscal devaluation is the best option for a country that wants to expand its GDP. The output effects become less favorable when several countries implement fiscal devaluations in a coordinated way.

Next, we analyze the role of the degree of openness. As discussed in section 3, we set the share of imported goods in the 'Southern European countries' consumption basket to match the empirically observed import-to-GDP ratio. In comparison, Lipinska and von Thadden (2012) set the share of 
imported goods to 25 percent in both countries (that are of equal size). In an alternative scenario, we set $\omega=0.25$ which implies that the share of imported goods in 'Central-Northern European countries' consumption basket $\left(\omega^{*}\right)$ must be changed to 0.13 percent. Lipinska and von Thadden (2012) show that the introduction of home bias slightly dampens the effect of a fiscal devaluation on output in the long term. Row 7 of Table 2 shows that our findings complement their findings. In a more closed economy the expenditure switching effect is smaller and consequently the effect of a fiscal devaluation becomes weaker in the short term.

A potentially important parameter is the Frisch elasticity of labor supply. Lipinska and von Thadden (2012) set it to 0.4, whereas we set it to one in our benchmark parameterization. In an alternative scenario, we set $\emptyset=2.5$. This implies that the Frisch elasticity, which is $1 / \varnothing$ in our model, is 0.4 . Row 8 of Table 2 shows that the effects of varying the Frisch elasticity are negligible. Also in the alternative scenario we find a much stronger output effect than Lipinska and von Thadden (2012).

As discussed by IMF (2011), for instance, the effectiveness of a fiscal devaluation requires nominal wage rigidities. The increase in VAT reduces real wages, and labor unions respond to this by aiming to increase their nominal wages. This increases marginal costs, offsetting the benefits of a reduction in the SCR rate. In our model, due to the Calvo-pricing mechanism, this takes time. Row 9 of Table 2 shows that the effectiveness of the fiscal devaluation is significantly muted when wages are flexible: the peak effect on output falls to 0.25 percent. In this case, wages adjust upwards in 'Southern European countries' immediately after the fiscal devaluation. As a consequence, real marginal costs adjust immediately upwards to the new level. This implies that the expenditure switching effect virtually disappears.

Finally, we analyze how sensitive our results are to modeling a fiscal devaluation in terms of a reduction in the SCR, as opposed to modeling it in terms of a reduction in the labor income tax rate. Lipinska and von Thadden (2012) model a fiscal devaluation as a reduction in the labor income tax rate. In order to show that their experiment results in much lower output effects in our model as well, we set the SCR rate to zero and replace it by a labor income tax. The budget constraints of Ricardian and non-Ricardian households are now

$$
\begin{gathered}
B_{t+1}+\left(1+\tau_{t}^{V A T}\right) P_{t} C_{t}^{R H}=R_{t-1} B_{t}+\left(1-\tau_{t}^{w}\right) W_{t} N_{t}^{R H}+\Pi_{t}-T_{t}, \\
\left(1+\tau_{t}^{V A T}\right) P_{t} C_{t}^{N R}=\left(1-\tau_{t}^{w}\right) W_{t} N_{t}^{N R}-T_{t},
\end{gathered}
$$

respectively, where $\tau_{t}^{w}$ is the labor income tax. We now model a fiscal devaluation as a shift from wage income tax to VAT equivalent of 1 percent of ex post GDP. This implies that the labor income tax needs to be reduced by 1.11 percentage points, whereas the VAT rate needs to be increased by 1 percentage point. Row 10 of Table 2 shows that the peak effect of output is reduced to 0.293 percent. The peak effect on output in case of the labor income tax shock is roughly one quarter that of case where a fiscal devaluation is modeled as a change in the SCR rate.

\section{Conclusion}

Correcting the loss of competitiveness in 'Southern European countries' and the current account imbalance between 'Central-Northern European countries' and 'Southern European countries' are challenging jobs for the euro area. We found that-assuming sticky wages—a fiscal devaluation, of 1 percent of GDP, increases output in 'Southern European countries' by 0.9-1.4 percent, depending on 
the parameterization. In our model, a fiscal devaluation is much more effective in terms of stimulating domestic short-term output than earlier models have found. Furthermore, a fiscal devaluation entails a structural improvement, because it has a positive effect on output in the long term. Our findings suggest that a fiscal devaluation could be used as a part of a policy package aimed at increasing output in in 'Southern European countries'. The advantageous short-term effects of a fiscal devaluation however should not be overemphasized: a fiscal devaluation, under the benchmark parameterization, depreciates the real exchange rate by 0.3 percent and improves the trade balance by 0.2 percent of GDP, which are quite small effects. Our findings therefore suggest that a fiscal devaluation alone would not be sufficient to correct the divergence in competitiveness and the current account imbalance between the 'Southern countries' and 'Central-Northern countries' in the euro area. A fiscal devaluation can be a useful reform to make progress in this direction. It should however be part of a wider package of economic policy reforms aimed at increasing the competitiveness of 'Southern European countries', including product and labor market reforms and wage moderation, for instance.

\section{Acknowledgements}

This research was supported by the Deutsche Forschungsgemeinschaft through the SFB 649 Economic Risk. We thank Helge Berger, Fabian Bornhorst, Ruud de Mooij, Greetje Everaert, Francesco Franco, Keiko Honjo, Michael Keen, Wojtek Maliszewski, Jochen Mankart and Kazuko Shirono for helpful comments and suggestions. The opinions presented are those of the authors and should not be attributed to the International Monetary Fund, its Executive Board or its management. 


\section{References}

Adolfson, M., Laseen, S., Linde, J., Villani,M. 2007. Bayesian estimation of an open economy DSGE model with incomplete pass-through. Journal of International Economics 72, 481-511.

Arnold, J. M., Brys, B., Heady, C., Johansson, A., Schwellnus, C., Vartia, L. 2011. Tax policy for economic recovery and growth. Economic Journal 121, F59-F80.

Bank of Portugal. 2011. The impact of a tax change aimed at increasing the external competitiveness of the Portuguese economy. Economic Bulletin 17, 39-42.

Bergin, P. R. 2006. How well can the new open economy macroeconomics explain the exchange rate and current account?. Journal of International Money and Finance 25, 675-701.

Bils, M., Klenow, P. J. 2004. Some evidence on the importance of sticky prices. Journal of Political Economy 112, 947-985.

Broda, C., Weinstein, D. E. 2006. Globalization and the gains from variety. Quarterly Journal of Economics 12, 541-585.

Boscá, J.E., Doménecha R., Ferria, J. 2012. Fiscal Devaluations in EMU. BBVA Working Paper $12 / 11$.

Campbell, J. Y., Mankiw, N. G. 1990. Permanent income, current income, and consumption. Journal of Business \& Economic Statistics 8, 265-279.

Calvo, G. A. 1983. Staggered prices in a utility maximizing framework. Journal of Monetary Economics 12, 383-398.

CPB. 2013. Study on the impacts of fiscal devaluation. European Commission Taxation Papers 36-13.

Coenen, G., Lombardo, G., Smets, F. and Straub, R. 2010. International transmission and monetary policy cooperation, in: Gali, J. Gertler, M. J. (eds.) International Dimensions of Monetary Policy, University of Chicago Press, Chicago, pp. 157-192.

Gourinchas, P-O., Obstfeld, M. 2012. Stories of the twentieth century for the twenty-first. American Economic Journal: Macroeconomics 4, 226-265.

de Mooij, R., Keen, M. 2013. 'Fiscal devaluation' and fiscal consolidation: the VAT in trouble times, in: Alesina, A. Giavazzi, F. (eds.) Fiscal Policy after the Financial Crisis, University of Chicago Press, Chicago, pp. 443-485.

Druant, M., Fabiani, S., Kezdi, G. Lamo, A., Martins, F., Sabbatini, R. 2009. How are firms’ wages and prices linked: Survey evidence in Europe. European Central Bank Working Paper Series 1084.

European Commission, 2006. Macroeconomic effects of a shift from direct to indirect taxation: A simulation for $15 \mathrm{EU}$ member states. Note presented by the EC services at the 72nd meeting of the OECD Working Party No. 2 on Tax Policy Analysis and Tax Statistics, Paris.

Eurostat, 2013, Statistics, Available online at http://epp.eurostat.ec.europa.eu/portal/page/portal/statistics/themes (accessed on 1.11.2013) 
Farhi, E., Gopinath, G. Itskhoki, O. 2013. Fiscal devaluations. Review of Economic Studies, forthcoming.

Feenstra, R. C., Obstfeld, M. Russ, K. N. 2012. In search of the Armington elasticity, mimeo.

Franco, F., 2010. Improving competitiveness through fiscal devaluation, the Case of Portugal. mimeo.

Franco, F., 2011. Adjusting to external imbalances within the EMU, the case of Portugal. mimeo.

Galí, J. 2011. Unemployment Fluctuations and Stabilization Policies: A New Keynesian Perspective. MIT Press, Massachusetts.

Galí, J., López-Salido, J. D., Vallés, J. 2007. Understanding the effects of government spending on consumption. Journal of the European Economic Association 5, 227-270.

IMF 2011. Fiscal Monitor: Addressing Fiscal Challenges to Reduce Economic Risks. International Monetary Fund, Washington DC.

Ivanova, A. 2012. Current account imbalances: can structural policies make a difference?. International Monetary Fund Working Paper 12/61.

Kemmerling, A. 2009. Taxing the working poor: The political origins and economic consequences of taxing low wage. Edward Elgar Publishing, Cheltenham.

Keynes, J. M. 1931, Addendum to: Great Britain. Committee on Finance and Industry Report [Macmillan Report] (London: His Majesty’s Stationery Office, 1931) 190-209. Reprinted in Donald Moggridge, The Collected Writings of John Maynard Keynes, vol. 20 (London: Macmillan and Cambridge: Cambridge Press for the Royal Economic Society, 1981), 283309.

Kimball, M., Shapiro, M. 2008. Labor supply: are income and substitution effects both large or both small. NBER working paper 14208.

Kormilitsina, A., Nekipelov, D. 2012. Approximation properties of Laplace-type estimators, in: Balke, N., Canova, F., Milani, F., Wynne, M. A. (eds.) DSGE Models in Macroeconomics: Estimation, Evaluation, and New Developments, Emerald Group Publishing, Bingley, pp. 291-318.

Lipinska, A., von Thadden, L., 2012. On the (in)effectiveness of fiscal devaluations in a monetary union. Board of Governors of the Federal Reserve System: Finance and Economics Discussion Series 2012-71.

Mian, A., Sufi, A., 2010. Household leverage and the recession of 2007-09. IMF Economic Review $58,74-117$.

Mundell, R., 1961. A theory of optimum currency areas. American Economic Review 51, 657-665.

Reinhart, C., Rogoff, K., 2009. This Time Is Different: Eight Centuries of Financial Folly. Princeton University Press, Princeton.

Schmit-Grohé, S., Uribe, M. 2003. Closing small open economy models. Journal of International Economics 61, 163-185. 
Taylor, J. B. 1993. Discretion versus policy rules in practice. Carnegie-Rochester Conference Series on Public Policy 39, 195-214.

World Bank, 2013, World DataBank, Available online at http://databank.worldbank.org/data/home.aspx (accessed on 28.10.2013). 


\section{Diskussionsbeiträge - Fachbereich Wirtschaftswissenschaft - Freie Universität Berlin Discussion Paper - School of Business and Economics - Freie Universität Berlin}

2013 bereits erschienen:

2013/1 MASSARRAT-MASHHADI, Nima

The mutual impact of deferral labour taxation and capital income taxation on risk-taking behaviour : an experimental analysis

FACTS

2013/2 ENGLER, Philipp und Simon VOIGTS

A Transfer Mechanism for a Monetary Union

Economics

2013/3 CHADI, Adrian und Clemens HETSCHKO

Flexibilisation without Hesitation? : temporary contracts and workers' satisfaction

Economics

2013/4 HOLTFRERICH, Carl-Ludwig

Government Debt in Economic Thought of the Long 19th Century

Economics

2013/5 BESTER, Helmut und Daniel KRÄHMER

Exit Options and the Allocation of Authority

Economics

2013/6 BESTER, Helmut und Johannes Münster

Subjective Evaluation versus Public Information

Economics

2013/7 JENDERNY, Katharina

Mobility of Top Incomes in Germany

Economics

2013/8 SKUPNIK, Christoph

"Welfare magnetism" in the EU-15? : why the EU enlargement did not start a race to the bottom of welfare states

Economics

2013/9 MUCHLINSKI, Elke

Die Unzweckmäßigkeit physikalischer Metaphern und Begriffe für die Ökonomie als Erfahrungswissenschaft

Economics

2013/10 SCHREIBER, Sven

(When) Does Money Growth Help to Predict Euro-area Inflation at Low Frequencies?

Economics

2013/11 KNOLL, Martin

The Heavily Indebted Poor Countries and the Multilateral Debt Relief Initiative :

a Test Case for the Validity of the Debt Overhang Hypothesis

Economics 
$2013 / 12$

CORNEO, Giacomo

Work Norms, Social Insurance and the Allocation of Talent

Economics

2013/13 GRIGORIADIS, Theocharis und Benno TORGLER

Religious Identity, Public Goods and Centralization : Evidence from Russian and Israeli Cities

Economics

2013/14 GRIGORIADIS, Theocharis

A Political Theory of Russian Orthodoxy Evidence from Public Goods

Experiment

Economics

2013/15 HECHTNER, Frank

Ökonomische Anreizwirkungen im bundesstaatlichen Finanzausgleich

FACTS

2013/16 GRIGORIADIS, Theocharis

Religious Origins of Democracies and Dictatorships

Economics

2013/17 ECKERSTORFER, Paul; Viktor STEINER und Florian WAKOLBINGER

Steuerreformvorschläge in der Diskussion - eine Mikrosimulationsanalyse der Aufkommens-, Beschäftigungs- und Verteilungswirkungen für Österreich Economics 